Revista Eletrônica de Direito Processual - REDP.

Rio de Janeiro. Ano 11. Volume 18. Número 1. Janeiro a Abril de 2017

Periódico Quadrimestral da Pós-Graduação Stricto Sensu em Direito Processual da UERJ

Patrono: José Carlos Barbosa Moreira. ISSN 1982-7636. pp. 42-67

www.redp.uerj.br

\title{
DELAÇÃO PREMIADA E DIREITOS FUNDAMENTAIS DO SUJEITO PASSIVO \\ DA PERSECUÇÃo PENAL A PARTIR DA REGULAMENTAÇÃo CONSTANTE NA LEI 12.850/2013 ${ }^{1}$
}

STATE`S EVIDENCE AND FUNDAMENTAL RIGHTS OF THE PASSIVE

SUBJECT OF CRIMINAL PERSECUTION AS A RESULT OF THE REGULATION

INSERTED IN LAW 12.850/2013

Américo Bedê Freire Júnior

Doutor em Direito pela FDV/ES. Professor do Programa de Pós-Graduação da FDV/ES. Juiz Federal Titular da $2^{\text {a }}$ Vara Federal Criminal de Vitória/ES. bede@jfes.jus.br

Willy Potrich da Silva Dezan

Mestrando em Direitos e Garantias Fundamentais pela Faculdade de Direito de Vitória - FDV. Advogado. willypotrich@hotmail.com

RESUMO: O Direito Penal - e o Direito Processual que cuida de sua efetivação funciona, a um só tempo, como mecanismo à disposição do Estado para concretizar seu poder punitivo e como limite ao exercício desse mesmo poder. Esta segunda acepção simboliza o que se convencionou chamar de humanização do Direito Penal, marcada pela compreensão de diversos direitos e garantias voltadas à proteção do sujeito passivo da persecução penal. O instituto da delação premiada, como método pouco ortodoxo, utilizado especialmente no combate à criminalidade organizada, fez surgir na doutrina expressiva cizânia acerca de sua compatibilidade com o atual sistema de direitos e garantias desenhado na Constituição Federal, de modo que não são escassas as referências à delação como prática policialesca, de exceção, responsável pela involução do Direito Penal. Contudo, especialmente a partir do advento da nova legislação de combate à criminalidade organizada, a colaboração premiada ganhou novo fôlego teórico e prático no Brasil, com

\footnotetext{
${ }^{1}$ Artigo recebido em 06/03/2017 e aprovado em 19/04/2017.
} 
Revista Eletrônica de Direito Processual - REDP.

Rio de Janeiro. Ano 11. Volume 18. Número 1. Janeiro a Abril de 2017

Periódico Quadrimestral da Pós-Graduação Stricto Sensu em Direito Processual da UERJ

Patrono: José Carlos Barbosa Moreira. ISSN 1982-7636. pp. 42-67

www.redp.uerj.br

ampla aceitação jurisprudencial, recomendando que se aprecie com acuidade não apenas seus contornos dogmáticos, mas também a pertinência das críticas que lhe são dirigidas.

PALAVRAS-CHAVE: Direito Penal. Direito Processual Penal. Delação Premiada. Direitos e Garantias Fundamentais.

ABSTRACT: The Criminal Law - and the Procedural Law that takes care of its effectiveness - works, at the same time, as a mechanism available to the State to realize its punitive power and as a limit to the exercise of this same power. This second meaning represents what has been called the humanization of criminal law, marked by the understanding of several rights and guarantees intended to protect the subject of criminal prosecution. The institute of state`s evidence, as an unorthodox method, used especially in the fight against organized crime, raised expressive mistrust in the doctrine about its compatibility with the current system of rights and guarantees designed in the Federal Constitution, so that references to the institute as police practice, exceptional, responsible for the involution of Criminal Law, are very common. However, especially since the advent of the new legislation to combat organized crime, the state`s evidence has gained new theoretical and practical inspiration in Brazil, with wide acceptance of jurisprudence, recommending that it be appreciated with accuracy not only its theoretical aspects, but also the criticisms relevance.

KEYWORDS: Criminal Law. Criminal Procedural Law. State`s Evidence. Fundamental Rights and Guarantees.

\section{INTRODUÇÃO}

Os recentes acontecimentos políticos do país, impulsionados pela imprevisibilidade dos caminhos trilhados pelas gigantescas operações policiais de combate ao crime organizado no setor público, pôs em voga o instituto da delação premiada, bem como sua compatibilidade com os princípios que orientam o direito processual penal brasileiro ${ }^{2}$.

\footnotetext{
${ }^{2}$ A referência que se faz é à denominada Operação Lava-Jato, concebida no âmbito da Polícia Federal e do Ministério Público Federal de Curitiba-PR, e desenvolvida, inicialmente, perante a Justiça Federal daquela
} 
Revista Eletrônica de Direito Processual - REDP.

Rio de Janeiro. Ano 11. Volume 18. Número 1. Janeiro a Abril de 2017

Periódico Quadrimestral da Pós-Graduação Stricto Sensu em Direito Processual da UERJ

Patrono: José Carlos Barbosa Moreira. ISSN 1982-7636. pp. 42-67

www.redp.uerj.br

Embora tenha recebido maior atenção legislativa, pela primeira vez, a partir da

edição da Lei 12.850/2013 (Lei de Combate ao Crime Organizado), é certo que o instituto não é nenhuma novidade, contando com previsão expressa desde, pelo menos, a edição da Lei 8.072/90 (Lei dos Crimes Hediondos), sem se ignorar a referência comum à época das Ordenações Filipinas ${ }^{3}$.

Fato é que, desde que surgiu em nosso direito, a delação premiada vem sendo observada com bastante desconfiança pela maior parte dos estudiosos do direito penal e processual penal. Desde questionamentos relacionados ao comportamento antiético do delator, aos efeitos práticos gerados pelas declarações daquele que colabora com a justiça, para si próprio ou perante terceiros, vários são os argumentos que visam a demonstrar a inadequação do instituto em cotejo com nosso sistema penal e, especialmente, com as garantias constitucionais do sujeito passivo da persecução penal.

O presente trabalho buscará identificar as principais críticas doutrinárias dirigidas ao instituto da delação, bem como aferir se estas são capazes de inviabilizar a utilização do instituto na prática forense, por incompatibilidade com os princípios constitucionais.

A análise será feita, sobretudo, à luz das disposições constantes da Lei 12.850/13, de modo a identificar se as regras ali estabelecidas são suficientes para evitar eventuais vulnerações aos direitos e garantias fundamentais apontadas pela doutrina.

Antes, porém, respeitados os limites inerentes à brevidade do texto, traçará, em linhas gerais, um panorama acerca do instituto.

\section{BREVE PANORAMA ACERCA DA DELAÇÃO PREMIADA}

cidade, desde 2014. Após a adoção maciça da delação premiada como meio de obtenção de provas, a operação, que possuía como foco inicial esquemas de lavagem de dinheiro envolvendo operadores de câmbio, desdobrou-se em diversas outras investigações, alcançando, especialmente, um largo esquema de corrupção envolvendo o superfaturamento de contratos da Petrobras. Considerada a maior investigação de corrupção e lavagem de dinheiro da história do país, a operação já conta com 2 (dois) anos de duração, e graças à reiterada oxigenação produzida pelas revelações daqueles que decidem colaborar com a Justiça, parece não ter data para acabar. Informações disponíveis no sítio eletrônico do Ministério Público Federal (http://lavajato.mpf.mp.br/lavajato/index.html).

3 Segundo Walter Barbosa Bittar, já havia, nessa época (de 1603 a 1830) "a possibilidade de perdão para alguns casos de delação, de conspiração, ou conjuração, e de revelações que propiciassem a prisão de terceiros envolvidos com crimes que resultassem provados, funcionando a delação como causa de exculpação”. BITTAR, Walter Barbosa. Delação Premiada: Direito Estrangeiro, Doutrina e Jurisprudência. 2 ed. Rio de Janeiro: Lumen Juris, 2011. p. 83. 
Revista Eletrônica de Direito Processual - REDP.

Rio de Janeiro. Ano 11. Volume 18. Número 1. Janeiro a Abril de 2017

Periódico Quadrimestral da Pós-Graduação Stricto Sensu em Direito Processual da UERJ

Patrono: José Carlos Barbosa Moreira. ISSN 1982-7636. pp. 42-67

www.redp.uerj.br

Delatar, segundo o Dicionário Houaiss de Língua Portuguesa, significa "denunciar

a responsabilidade de alguém ou si mesmo por crime". O vocábulo "premiada", logo após "delação", completa não apenas o nome do instituto, mas fornece uma perfeita síntese de sua essência.

Em linhas gerais, a delação premiada pode ser definida como instituto de política criminal situada no âmbito da persecução penal, por meio do qual se busca, na figura do investigado, acusado ou mesmo condenado, uma fonte de informações para auxiliar o Estado no combate à criminalidade em troca de algum benefício relativo à sanção que deveria ser aplicada ao colaborador pelos seus próprios crimes.

Na definição de Walter Barbosa Bittar, cuida-se de um “instituto de Direito Penal que garante ao investigado, indiciado, acusado ou condenado, um prêmio, redução podendo chegar até a liberação da pena, pela sua confissão e ajuda nos procedimentos persecutórios, prestada de forma voluntária" 4 .

Guilherme de Souza Nucci, em termos mais objetivos, entende o instituto como a, “(...) possibilidade de se reduzir a pena do criminoso que entregar o(s) comparsa(s). É o ‘dedurismo' oficializado, que, apesar de moralmente criticável, deve ser incentivado em face do aumento contínuo do crime organizado"5.

É o mesmo Autor quem, compartilhando sentimento aparentemente comum a quem defende a compatibilidade da delação com nosso direito, adverte que:

É um mal necessário, pois trata-se da forma mais eficaz de se quebrar a espinha dorsal das quadrilhas, permitindo que um de seus membros possa se arrepender, entregando a atividade dos demais e proporcionando ao Estado resultados positivos no combate à criminalidade.

A advertência vem ao encontro dos fundamentos que lastreiam a colaboração premiada, fundada na premente necessidade de eficiência e celeridade na persecução criminal face às complexas manifestações da atividade criminosa, organizada e enraizada

\footnotetext{
${ }^{4}$ BITTAR, Walter Barbosa.Delação Premiada: Direito Estrangeiro, Doutrina e Jurisprudência. 2 ed. Rio de Janeiro: Lumen Juris, 2011. p. 5.

${ }^{5}$ NUCCI, Guilherme de Souza. Manual de Direito Penal: parte geral: parte especial. $3^{\text {a }}$ Ed. São Paulo: Editora Revista dos Tribunais, 2007, p. 716.
} 
Revista Eletrônica de Direito Processual - REDP.

Rio de Janeiro. Ano 11. Volume 18. Número 1. Janeiro a Abril de 2017

Periódico Quadrimestral da Pós-Graduação Stricto Sensu em Direito Processual da UERJ

Patrono: José Carlos Barbosa Moreira. ISSN 1982-7636. pp. 42-67

www.redp.uerj.br

nos mais diversos segmentos e instituições, de estrutura quase impenetrável e de perversa nocividade social.

Não é por outra razão, aliás, que a regulamentação mais cuidadosa do instituto da delação premiada em nosso direito tenha surgido, justamente, com o advento da Lei que define e institui métodos de combate às organizações criminosas, manifestação máxima da nova criminalidade e expositor persistente da deficiência estatal no seu combate a partir dos métodos ordinários à sua disposição.

Guardado o momento devido para se apreciar os argumentos favoráveis e contrários ao instituto, é fato que a regulamentação esboçada pelo advento da Lei 12.850/2013 fez perder sentido algumas inseguranças doutrinárias a respeito da formação e da validade da delação premiada, bem como dos benefícios a serem concedidos ao colaborador.

Como deixa claro o art. $4^{\circ}$ do Diploma em comento, a colaboração deve ser voluntária e eficiente, sendo acompanhada da confissão dos crimes cometidos pelo próprio delator, com expressa renúncia ao direito ao silêncio, o que acarreta, consequentemente, o dever de dizer a verdade.

O delator deve estar acompanhado de seu defensor em todos os atos, e suas declarações, caso sejam voltadas à revelação de novos fatos criminosos e de participação de terceiros, devem ser acompanhadas de elementos que permitam aos órgãos estatais avançar na investigação e comprovar as imputações.

São, portanto, requisitos para a formação da colaboração premiada, que as declarações do agente (a) sejam prestadas de forma voluntária, (b) acompanhadas de sua confissão a respeito dos fatos que lhe são atribuídos, (c) com a integral assistência de seu advogado, (d) de modo a garantir resultados eficazes ao Estado, (e) inclusive com a apresentação de provas ou a revelação de caminhos para confirmação do que é relatado.

A voluntariedade pressupõe a vontade livre e consciente de colaborar com o Estado, sem a influência de pressões diretas (como a ameaça de aplicação de sanções mais greves diante da recusa, por exemplo) ou indiretas (como a utilização de prisões provisórias para estimular a colaboração).

Ainda que surja como uma estratégia de defesa para evitar a imposição das penas ordinárias para os delitos praticados, a iniciativa de colaborar deve surgir do interesse legítimo do próprio agente colaborador, sem prejuízo de que seja ofertado pelos órgãos de 
Revista Eletrônica de Direito Processual - REDP.

Rio de Janeiro. Ano 11. Volume 18. Número 1. Janeiro a Abril de 2017

Periódico Quadrimestral da Pós-Graduação Stricto Sensu em Direito Processual da UERJ

Patrono: José Carlos Barbosa Moreira. ISSN 1982-7636. pp. 42-67

www.redp.uerj.br

acusação algum benefício em troca de uma postura cooperativa (o que, afinal, não pode ser tachado como coação, já que a troca é inerente à própria essência do instituto).

Evidentemente, a colaboração deve estar acompanhada da confissão do colaborador a respeito de sua própria conduta criminosa. A construção dogmática da delação premiada pressupõe um certo grau de culpabilidade do delator, sem o qual não haverá sentido a negociação sobre a pena aplicada. Afinal, não poderia o legislador prever e o juiz aplicar qualquer sanção a um colaborador inocente.

Além disso, e especialmente em delitos envolvendo organizações criminosas, não parece razoável que um inocente possua informações que tornassem eficaz sua colaboração. Apenas poderá fornecer detalhes a respeito do funcionamento de uma organização criminosa quem dela participa ou participou de alguma maneira.

Como forma de garantir a voluntariedade nas declarações - inclusive na confissão bem como a ciência do colaborador a respeito das consequências da postura adotada, deverão todos os atos relativos à delação serem acompanhados pela defesa técnica, sob pena de invariável nulidade.

Não é suficiente, contudo, a confissão acompanhada de qualquer declaração. Para fazer jus aos benefícios legais, as declarações do colaborador devem ser eficazes, capazes de fornecer ao Estado, pelo menos, um dos resultados previstos nos incisos do art. $4^{\circ}$ da Lei 12.850/2013, quais sejam, (a) a identificação dos demais coautores e partícipes da organização criminosa e das infrações penais por eles praticadas, (b) a revelação da estrutura hierárquica e da divisão de tarefas da organização criminosa, (c) a prevenção de infrações penais decorrentes das atividades da organização criminosa, (d) a recuperação total ou parcial do produto ou do proveito das infrações penais praticadas pela organização criminosa ou (e) a localização de eventual vítima com a sua integridade física preservada.

As declarações devem, ainda, estar acompanhadas de elementos que demonstrem sua veracidade ou, no mínimo, apoiadas em diretrizes fornecidas pelo colaborador para permitir que os órgãos responsáveis pela persecução estatal possam aprofundar as investigações e obter os resultados previstos no art. $4^{\circ}$ da Lei 12.850/13.

Ao lado desses requisitos, o $\S 6^{\circ}$ do art. $4^{\circ}$ da Lei 12.850/13 prevê ainda que "o juiz não participará das negociações realizadas entre as partes para a formalização do acordo de colaboração". Como forma de preservar sua imparcialidade, deve o julgador manter-se 
Revista Eletrônica de Direito Processual - REDP.

Rio de Janeiro. Ano 11. Volume 18. Número 1. Janeiro a Abril de 2017

Periódico Quadrimestral da Pós-Graduação Stricto Sensu em Direito Processual da UERJ

Patrono: José Carlos Barbosa Moreira. ISSN 1982-7636. pp. 42-67

www.redp.uerj.br

equidistante das partes, limitando sua atuação à verificação do preenchimento dos requisitos legais e ao respeito dos direitos fundamentais do colaborador ${ }^{6}$.

Caso reste frustrada a delação em razão da superveniência de provas de que os fatos declarados ou imputados a terceiros são inverídicos, além de perder os benefícios do acordo, o colaborador também responderá pelo delito previsto no art. 19 da Lei 12.850/137 .

Por outro lado, a eficácia da colaboração impõe seja concedido ao colaborador um dos benefícios previstos no caput do art. $4^{\circ}$ da Lei. São eles, (a) o perdão judicial, (b) a redução em até $2 / 3$ (dois terços) da pena privativa de liberdade, (c) sua substituição por pena restritiva de direitos ou (d) o não oferecimento de denúncia.

Por expressa previsão legal, este último benefício - o não oferecimento de denúncia - apenas poderá ser concedido ao colaborador que, cumulativamente, não for o líder da organização criminosa e for o primeiro integrante da organização a prestar efetiva colaboração ( $\$ 4^{\circ}$, I e II do art. $4^{\circ}$ da Lei $\left.12.850 / 13\right)$.

Os demais benefícios serão negociados com maior liberdade entre a defesa e a acusação, sem prejuízo de que, revelando-se especialmente útil a colaboração, possa o Ministério Público ou o delegado de polícia pleitear a concessão do perdão judicial, ainda que não originalmente previsto no acordo.

Caso a colaboração ocorra apenas em momento posterior à sentença, os benefícios estarão limitados à redução da pena aplicada pela metade, ou à progressão de regime, ainda que não alcançados os requisitos legais para tanto.

Expostas as principais características do instituto da colaboração, resta mais simples a identificação de sua natureza jurídica. Por se tratar de ato complexo, que gera consequências não apenas para o colaborador, mas também para os delatados, não parece ser possível entender a delação premiada como uma unidade indivisível.

Embora não seja o objetivo deste trabalho o aprofundamento a respeito da natureza jurídica do instituto, melhor parece o entendimento no sentido de que a colaboração possui

\footnotetext{
${ }^{6}$ A própria lei afasta o magistrado dessa postura meramente fiscalizatória quando, na parte final do $\S 8^{\circ}$ do mesmo dispositivo, estatui que "o juiz poderá recusar homologação à proposta que não atender aos requisitos legais, ou adequá-la ao caso concreto". Deve-se entender, por coerência ao $\S 6^{\circ}$ e à luz do princípio acusatório, que essa adequação apenas poderá recair sobre eventuais violações aos dispositivos legais ou como forma de evitar lesão a direito fundamental do réu. Jamais poderá o magistrado interferir nos termos da negociação, os quais ficarão a cargo da negociação levada a efeito entre a defesa e a acusação.

${ }^{7}$ Art. 19. Imputar falsamente, sob pretexto de colaboração com a Justiça, a prática de infração penal a pessoa que sabe ser inocente, ou revelar informações sobre a estrutura de organização criminosa que sabe inverídicas:

Pena - reclusão, de 1 (um) a 4 (quatro) anos, e multa.
} 
Revista Eletrônica de Direito Processual - REDP.

Rio de Janeiro. Ano 11. Volume 18. Número 1. Janeiro a Abril de 2017

Periódico Quadrimestral da Pós-Graduação Stricto Sensu em Direito Processual da UERJ

Patrono: José Carlos Barbosa Moreira. ISSN 1982-7636. pp. 42-67

www.redp.uerj.br

natureza dúplice. Por um lado, em relação àquele que revela informações e entrega seus

comparsas, cuida-se de verdadeira confissão. Menos simplória, contudo, é a análise em relação aos delatados. É que, como bem recorda a doutrina, não se este diante de uma prova verdadeiramente testemunhal, já que o colaborador não é um terceiro desinteressado no resultado do processo, e suas palavras possuem valor bastante limitado. Pertinente, pois, neste ponto, a tentativa de identificar a colaboração como espécie de testemunho impróprio.

Estabelecidos os contornos essenciais do objeto de estudo, passa a abordar as críticas mais comuns dirigidas à colaboração.

\section{PRINCIPAIS OBJEÇÕES DOUTRINÁRIAS E SUA PERTINÊNCIA}

\subsection{O PROBLEMA DOS INOCENTES ${ }^{8}$}

A partir de uma visão ampla, a delação premiada pode ser entendida como espécie de manifestação de consenso dentro do processo penal, ao lado de institutos como a transação penal e a suspensão condicional do processo $^{9}$, no direito brasileiro, e da plea bargain estadunidense ${ }^{10}$, como expressão máxima da justiça penal negociada no direito estrangeiro.

\footnotetext{
${ }^{8}$ A expressão advém de crítica cunhada por Vinicius Gomes de Vasconcellos. VASCONCELLOS, Vinicius Gomes de. Barganha e Justiça Criminal Negocial: análise das tendências de expansão dos espaços de consenso no processo penal democrático. São Paulo, IBCCrim: 2015.

${ }^{9}$ Institutos com previsão na Lei 9.099/95 (Lei dos Juizados Especiais), e que visam à abreviação do processo criminal, sem implementação da fase instrutória e sem a necessidade de prolação de uma sentença que resolva a controvérsia entre a acusação e a defesa.

${ }^{10}$ Modelo marcado pela intensa liberdade conferida à acusação para determinar não apenas as penas que serão aplicadas ao réu, mas até mesmo delimitar quais serão os crimes objeto de imputação. Cuida-se do exemplo mais radical que se tem notícia a respeito da justiça criminal negociada, que se contenta com uma mera declaração de culpa, em completa eliminação do ônus probatório da acusação. $\mathrm{O}$ instituto recebe críticas duríssimas de doutrinadores de diversos países. Em língua portuguesa, conferir a obra de Vinicus Gomes de Vasconcellos. VASCONCELLOS, Vinicius Gomes de. Barganha e Justiça Criminal Negocial: análise das tendências de expansão dos espaços de consenso no processo penal democrático. São Paulo, IBCCrim: 2015.
} 
Revista Eletrônica de Direito Processual - REDP.

Rio de Janeiro. Ano 11. Volume 18. Número 1. Janeiro a Abril de 2017

Periódico Quadrimestral da Pós-Graduação Stricto Sensu em Direito Processual da UERJ

Patrono: José Carlos Barbosa Moreira. ISSN 1982-7636. pp. 42-67

www.redp.uerj.br

Em traços gerais, essas expressões de justiça negocial penal podem ser definidas, unitariamente, como:

(...) um modelo que se pauta pela aceitação (consenso) de ambas as partes acusação e defesa - a um acordo de colaboração processual com o afastamento do réu de sua posição de resistência, em regra impondo o encerramento antecipado, abreviação, supressão integral ou de alguma fase do processo , fundamentalmente com o objetivo de facilitar a imposição de uma sanção penal com algum percentual de redução, o que caracteriza o benefício ao imputado em razão da renúncia ao devido transcorrer do processo penal com todas as garantias a ele inerentes ${ }^{11}$.

A contextualização é pertinente pois, uma vez inserta nesse âmbito, a colaboração premiada compartilha de diversas objeções acadêmicas voltadas às expressões de justiça negocial de modo geral.

De todas, nesse contexto, a mais relevante objeção repousa no denominado "problema dos inocentes". Alerta-se que a possibilidade de se obter um benefício relevante com a cooperação processual, aliada à expectativa de uma pena mais grave caso o processo siga seu trâmite regular, poderia gerar delações baseadas em falsas confissões, com a consequente punição de inocentes.

Sem dúvidas, quando se trata de outras manifestações de espaços de consenso no processo penal ( $v . g$ o instituto da transação penal), a crítica se faz bastante pertinente, sobretudo quando a lei não cuida de mecanismos internos aos institutos regulados capazes de evitar esse tipo de situação.

Contudo, a delação premiada, quando comparada às demais modalidades de acordos sobre sentença em processo penal, aparece munida de mecanismos capazes de minimizar, e muito, os riscos de se aplicar qualquer sanção a um inocente.

$\mathrm{Na}$ delação, o caráter coercitivo natural gerado pelos benefícios oferecidos ao agente em troca de sua confissão e consequente colaboração com a persecução penal é

\footnotetext{
${ }^{11}$ VASCONCELLOS, Vinicius Gomes de. Barganha e Justiça Criminal Negocial: análise das tendências de expansão dos espaços de consenso no processo penal democrático. São Paulo, IBCCrim: 2015. p. 68.
} 
Revista Eletrônica de Direito Processual - REDP.

Rio de Janeiro. Ano 11. Volume 18. Número 1. Janeiro a Abril de 2017

Periódico Quadrimestral da Pós-Graduação Stricto Sensu em Direito Processual da UERJ

Patrono: José Carlos Barbosa Moreira. ISSN 1982-7636. pp. 42-67

www.redp.uerj.br

mitigado pela necessidade de que o agente não se limite a confessar os fatos a si imputados, mas, também, fornecer informações capazes de ampliar a eficiência do Estado no combate à criminalidade.

Ora, para fornecer tais informações, o agente deve, necessariamente, ter conhecimento a respeito dos fatos criminosos. Por exemplo, em atividades investigativas ligadas à criminalidade organizada, apenas será possível a delação para o colaborador que participe ou tenha já participado de alguma forma das atividades ilícitas investigadas. Ou seja, àquele que não seja inocente.

Não se trata apenas de confessar ante o temor da aplicação de uma pena mais severa como resultado do exercício do contraditório e da ampla defesa em um processo marcado pela natural posição de resistência da defesa em relação à acusação. É necessário ir além, a um ponto que não se revela possível, em princípio, para aquele que seja inocente.

Além disso, há ainda uma espécie de coação inversa gerado pela previsão do art. 19 da Lei 12.850/13, que, como já visto, criminaliza a falsa delação. Assim, a falsa confissão, se acompanhada de falsa delação, pode ensejar a responsabilização criminal do delator, o que desencoraja esse tipo de atitude.

Por fim, mas não menos importante, dispõe o $§ 16$ do art. $4^{\circ}$ da Lei 12.850/13 que nenhuma condenação será proferida com base, exclusivamente, nas palavras do delator. Quer em relação aos delatados, quer em relação ao próprio delator, apenas será possível a prolação de uma sentença condenatória caso os termos da delação - no caso do delator, a sua confissão - esteja em consonância com as demais provas dos autos, como, de resto, já dispunha o art. 197 do CPP.

Compete, portanto, ao Magistrado, à luz das provas constantes dos autos, fazer o controle não apenas dos requisitos formais para a homologação da delação, mas também aferir, para aplicação da pena negociada, se a confissão está amparada por outros elementos constantes dos autos.

Em outras palavras, não se retira da acusação seu dever de colacionar aos autos elementos mínimos que indiquem a materialidade e a autoria delitiva, mantendo-se intacta a presunção de não culpabilidade que acompanha o réu até o trânsito em julgado da sentença penal condenatória. 
Revista Eletrônica de Direito Processual - REDP.

Rio de Janeiro. Ano 11. Volume 18. Número 1. Janeiro a Abril de 2017

Periódico Quadrimestral da Pós-Graduação Stricto Sensu em Direito Processual da UERJ

Patrono: José Carlos Barbosa Moreira. ISSN 1982-7636. pp. 42-67

www.redp.uerj.br

Deve-se lembrar, entretanto, que a Lei 12.850/13 admite a celebração de acordo de delação já na fase de execução penal, após o trânsito em julgado da sentença condenatória. Nesta hipótese, perde sentido a necessidade de se aferir o valor da confissão.

Em resumo, o que se observa é que a disciplina legal da delação premiada guarda mecanismos que, se corretamente aplicados, mitigam substancialmente os riscos de se homologar uma colaboração levada a efeito por pessoa inocente.

\subsection{A FALÊNCIA DO ESTADO E O INCENTIVO A CONDUTAS DESLEAIS}

Outra crítica comum na doutrina, esta específica ao instituto da delação premiada, consiste na afirmação de que a delação premiada, inobstante revele a deficiência estatal no combate à criminalidade, ainda o faz mediante o incentivo de condutas antiéticas, fundadas, basicamente, na traição.

Esta crítica, em verdade, se desdobra em duas. Por um lado, argumenta-se que a adoção da delação premiada como meio de obtenção de provas escancara a incapacidade do Estado em lidar com a denominada nova criminalidade. Além disso, a delação romperia com o compromisso estatal de atuação legítima ao longo de toda persecução penal, já que estaria fundada no estímulo a uma conduta desleal por parte dos colaboradores.

Quanto ao primeiro aspecto, parece insuperável o contrassenso.

Por um lado, é necessário reconhecer a constante evolução das atividades criminosas, acobertadas pela infiltração de suas práticas nas castas empresariais, administrativas e políticas, com a adoção de mecanismos e influências capazes de, cada vez mais, blindar seu funcionamento dos olhos do Estado.

Em contrapartida, pode-se questionar se, a esse mesmo Estado, deve-se preservar os meios arcaicos de persecução penal, pensados para um tipo bem menos sofisticado de criminalidade, admitindo, assim, o agigantamento do abismo entre a complexidade criminosa e a capacidade investigativa e punitiva das instituições?

O Estado deve se fingir forte, inabalável? Não deve ser dar ao luxo de admitir que seus recursos investigativos tradicionais remanescem falhos à criatividade delitiva? Deve permitir o alastramento de práticas perniciosas que atingem em larga escala toda a sociedade e culmina, ao fim, por corroer suas próprias bases de sustentação? 
Revista Eletrônica de Direito Processual - REDP.

Rio de Janeiro. Ano 11. Volume 18. Número 1. Janeiro a Abril de 2017

Periódico Quadrimestral da Pós-Graduação Stricto Sensu em Direito Processual da UERJ

Patrono: José Carlos Barbosa Moreira. ISSN 1982-7636. pp. 42-67

www.redp.uerj.br

Com deferência aos que levantam aludida objeção, não parece que o argumento possa ser usado em face da adoção ou do avanço da delação premiada.

Talvez seja até razoável apontar, com base nisso, a incapacidade do Estado em lidar, há tempos, com as efervescentes inovações em matéria de atividades criminosas. Mas cuidase de uma crítica direcionada à omissão do Estado, jamais sendo possível sua utilização como óbice à incorporação da delação.

Anda que se reconheça as potenciais tensões em relação aos direitos fundamentais dos acusados, geradas pela utilização da colaboração premiada, esse tipo de crítica apenas pode inviabilizar sua adoção se acompanhada de uma proposição igualmente eficaz, porém menos nociva a esses mesmos direitos, o que não ocorreu até o momento.

Sem isso, a objeção parece autofágica. Se há uma incapacidade a ser escancarada pelo uso da delação premiada é porque, antes dela, há também uma realidade social, ainda que de emergência - embora não se compartilhe desse pensamento, que reclama por mecanismos capazes de estancar essa mesma incapacidade.

Em relação ao segundo aspecto, a objeção se afigura ainda mais frágil, e se aflige dos mesmos contra-argumentos já utilizados.

Inadmitir a delação em razão de um suposto fomento a atitudes antiéticas de delatores chega a soar escorchante, como nota digna, apenas, de um Estado utópico de ética e bemestar social.

Será que o Estado deve mesmo se preocupar em preservar o comportamento ético entre criminosos? Seria essa uma pauta legítima? Seria um bem fundamental que deveria ser resguardado às custas de todas as mazelas sociais geradas pela criminalidade, especialmente a criminalidade organizada?

Parece-nos que não. Inexiste razões outras, senão culturais, para se entender que o réu deva sempre, e necessariamente, colocar-se sempre em posição de completa resistência em relação ao poder punitivo estatal.

$\mathrm{O}$ raciocínio talvez deva ser o inverso. Resguardado sempre o direito à não autoincriminação, e respeitada sempre a voluntariedade em qualquer conduta do réu no contexto da persecução penal, deve o direito encorajar o réu a colaborar com o Estado, especialmente no tocante aos crimes praticados por organizações criminosas. 
Revista Eletrônica de Direito Processual - REDP.

Rio de Janeiro. Ano 11. Volume 18. Número 1. Janeiro a Abril de 2017

Periódico Quadrimestral da Pós-Graduação Stricto Sensu em Direito Processual da UERJ

Patrono: José Carlos Barbosa Moreira. ISSN 1982-7636. pp. 42-67

www.redp.uerj.br

Vale lembrar, nas palavras de Márcio Barra Lima12, que a "solidariedade criminosa", responsável pela "lei do silêncio", é um dos elementos característicos das organizações criminosas, dificultando sobremaneira a penetração do Estado em suas estruturas e garantindo a perpetuação de sua existência. Se a colaboração afigura-se como um meio eficaz de romper com essa barreira, deve ser incentivada na medida do possível ${ }^{13}$.

Não se guarda a ingenuidade de acreditar que a colaboração advenha do arrependimento. Evidente que o que se visa, em regra, é a obtenção do prêmio legalmente previsto. Entretanto, talvez a conduta mais ética do criminoso, ao menos do ponto de vista da sociedade e do Estado seja, justamente, sua posição de não resistência e de colaboração com a justiça e com as atividades investigatórias do Estado.

Antiético seria o recuo do Estado na utilização da delação premiada por acreditar na necessidade de preservação de um pervertido código de ética criminoso.

É claro que se deve atentar para os riscos de o desejo de obtenção do prêmio acarretar delações falsas (v.g. o denominado dilema do prisioneiro ${ }^{14}$ ). No entanto, como já exposto linhas atrás, o instituto da colaboração premiada possui, em seu próprio regramento, mecanismos que, se bem aplicados, são capazes de impedir esse tipo de situação.

Basta lembrar, mais uma vez, que a condenação dos delatados não pode ter por fundamento único a palavra do delator, e que este, quando de sua colaboração, deve apresentar provas ou indicar caminhos investigativos que possam corroborar o que alega, sob pena de não ver homologado seu acordo, ou, ainda, de responder criminalmente por sua conduta.

\footnotetext{
${ }^{12}$ LIMA, Márcio Barra, A colaboração premiada como instrumento constitucionalmente legítimo de auxílio à atividade estatal de persecução criminal. In: CALABRICH, Bruno. FISCHER, Douglas. PELELLA, Eduardo. Garantismo Penal Integral: questões penais e processuais, criminalidade moderna e a aplicação do modelo garantista no Brasil. 1. ed. Salvador: Juspodivm, 2010.

${ }^{13}$ Os limites serão sempre os princípios constitucionais.

${ }^{14}$ Problema desenvolvido a partir da teoria dos jogos, no qual se expõe o dilema daquele que, sendo preso em conjunto com comparsa, tem a si apresentadas duas opções, quais sejam, (a) confessar sua participação ou (b) não confessar. Cada uma dessas opções, por seu turno, possuem dois desdobramentos possíveis, a depender da atitude do comparsa também preso, a quem serão apresentadas as mesmas duas opções. Neste caso, se ambos confessarem, ambos recebem uma pena reduzida. Se apenas um confessar e o outro negar sua participação, aquele que confessou receberá uma pena ainda menor, e o que resistiu será punido muito mais gravemente. Se ambos se mantiverem silentes, ambos terão pena reduzida. $\mathrm{O}$ dilema reside em saber a atitude do comparsa, o que faz com que o prisioneiro fique entre a lealdade a seu parceiro e a crença de que a lealdade é recíproca.
} 
Revista Eletrônica de Direito Processual - REDP.

Rio de Janeiro. Ano 11. Volume 18. Número 1. Janeiro a Abril de 2017

Periódico Quadrimestral da Pós-Graduação Stricto Sensu em Direito Processual da UERJ

Patrono: José Carlos Barbosa Moreira. ISSN 1982-7636. pp. 42-67

www.redp.uerj.br

3.3 A QUESTÃO DA CULPABILIDADE

Objeção bastante peculiar encontra-se na afirmação de que a adoção da colaboração premiada rompe com o princípio da culp, segundo o qual a pena deve ser aplicada na exata medida da culpa do réu.

Argumenta-se que os benefícios oferecidos ao delator em razão de sua conduta colaborativa deturpariam a função retributiva da sanção penal, enfraquecendo a credibilidade do sistema e banalizando a sensação de impunidade a partir da fixação de reprimendas inócuas diante de delitos de alta reprovabilidade. Seria, assim, uma forma de violação à proibição de proteção insuficiente.

A força do argumento não pode ser ignorada. De fato, cuida-se de um dos pontos mais sensíveis na disciplina dos acordos de colaboração, e que reclamam especial atenção e sensibilidade não apenas das instituições responsáveis pela persecução, mas também dos magistrados.

Há, na doutrina, quem entenda ser impossível falar em vulneração do princípio da culpabilidade ou da proporcionalidade da pena à gravidade do delito. Afinal, como garantia fundamental do sujeito passivo da persecução penal, tal princípio possuiria viés nitidamente individualista, cunhado com vistas a proteger o cidadão frente ao poder punitivo do Estado.

É nesse sentido o escólio de Frederico Valdez Pereira, para quem:

$\mathrm{O}$ aspecto limitador da culpabilidade se destina, fundamentalmente, a impedir a aplicação da pena para além da responsabilidade pessoal do acusado, de modo a que exigências de prevenção geral ou especial, que poderiam ensejar utilização da pena com alto rigor excessivo, visando a alcançar maior eficácia preventiva, estarão sempre limitadas à concreta culpabilidade manifestada no fato praticado pelo agente ${ }^{15}$.

15 PEREIRA, Frederico Valdez. Compatibilização Constitucional da Delação Premiada. Revista dos Tribunais, vol. 929, São Paulo, mar. 2013. p. 330. 
Revista Eletrônica de Direito Processual - REDP.

Rio de Janeiro. Ano 11. Volume 18. Número 1. Janeiro a Abril de 2017

Periódico Quadrimestral da Pós-Graduação Stricto Sensu em Direito Processual da UERJ

Patrono: José Carlos Barbosa Moreira. ISSN 1982-7636. pp. 42-67

www.redp.uerj.br

A ideia encontraria respaldo, ainda, na constatação de que o princípio da culpabilidade encontra-se constitucionalmente assentado, basicamente, sobre o pilar da dignidade da pessoa humana.

Não seria possível, portanto, a subversão de seu sentido de modo a inviabilizar os benefícios concedidos aos delatores e a própria utilização da delação premiada. Ao impedir a exacerbação da resposta penal do Estado, o princípio da culpabilidade não imporia a este mesmo Estado nenhuma medida mínima da punição a ser aplicada.

Não discorda o Autor, contudo, que o mesmo Direito Penal que se preocupa em impedir o excesso no poder punitivo do Estado deve também se preocupar em não aplicar penas insignificantes diante de fatos de alta gravidade e repercussão social.

Mas o que estaria em jogo aqui não seria mais o princípio da culpabilidade, e sim a medida com a qual o Estado protege os Direitos e Garantias Fundamentais dos cidadãos por meio do Direito Penal.

A distinção parece irrelevante em termos práticos. Afinal, seja a partir de uma visão da outra face do princípio da culpabilidade - de evitar punições aquém daquela recomendada pela culpabilidade - ou da medida na qual deve o Estado proteger os Direitos e Garantias Fundamentais, o que estará em voga será sempre, em última análise, a questão da vedação de proteção insuficiente dos bens jurídicos fundamentais à paz social.

No tocante à colaboração, vale lembrar que apenas fará jus ao benefício o colaborador que trouxer, de fato, informações úteis ao Estado no desmantelamento da atividade criminosa ou na recuperação dos produtos do crime. A norma é clara nesse sentido.

Cabe ponderar, também, que à luz da relevância dessa colaboração, o legislador já elaborou uma análise prévia da proporcionalidade dos benefícios concedidos em face dos resultados advindos da colaboração. Em linhas gerais, alcançado um ou mais dos resultados previstos nos incisos do art. $4^{\circ}$ da Lei 12.850/13, não acarretará insuficiência de proteção a bens jurídicos fundamentais a concessão de um dos benefícios previstos no caput do mesmo art. $4^{\circ}$.

Evidente que a medida da concessão ficará sempre a cargo do magistrado, guiado pela eficácia da colaboração (quantidade de bens recuperados, quantidade de pessoas identificadas e relevância destas no âmbito da organização etc.). 
Revista Eletrônica de Direito Processual - REDP.

Rio de Janeiro. Ano 11. Volume 18. Número 1. Janeiro a Abril de 2017

Periódico Quadrimestral da Pós-Graduação Stricto Sensu em Direito Processual da UERJ

Patrono: José Carlos Barbosa Moreira. ISSN 1982-7636. pp. 42-67

www.redp.uerj.br

O problema, portanto, está em identificar se esse controle prévio realizado pelo

legislador - e que será, posteriormente, complementado pelo magistrado - enseja, ou não, proteção insuficiente dos bens jurídicos tutelados pelo Direito Penal.

Antes, porém, é válido que se mencione as ponderações de Jorge Figueiredo Dias, para quem:

(...) excluir a questão da sanção do âmbito de validade do acordo significaria furtar a este o seu maior valor e interesse como pilar de um processo penal funcionalmente orientado: é precisamente em vista de uma limitação da normal discricionariedade (vinculada aos limites e procedimentos legais) de fixação da pena pelo julgador que o valor e o interesse jurídicoconstitucional e legal do acordo assumirão, na prática, o seu mais relevante significado $^{16}$.

Quer-se ilustrar, com isto, que a questão do benefício a ser concedido é o eixo central do funcionamento do instituto da delação premiada - como de resto será de qualquer manifestação de consenso no âmbito da persecução penal - e que, portanto, deve ser necessariamente trabalhada e entendida para viabilizar a existência das colaborações.

Em defesa dos benefícios concedidos, Frederico Valdez Pereira argumenta que:

(..) a alternativa ao não uso do dispositivo premial será, muito provavelmente, a prevalência da situação representada pela obstrução investigativa, portanto, estar-se-ia argumentando com a com o princípio da proibição de insuficiência na proteção penal para, em última análise, manter a situação de impasse na apuração de crimes que se buscou superar pelo recurso à colaboração premiada: a contradição parece insuperável. ${ }^{17}$

\footnotetext{
${ }^{16}$ DIAS, Jorge de Figueiredo. Acordos sobre a sentença em processo penal: o fim do Estado de Direito ou um novo princípio? Porto. Conselho Distrital do Porto: 2011. p. 51.

17 PEREIRA, Frederico Valdez. Compatibilização Constitucional da Delação Premiada. Revista dos Tribunais, vol. 929, São Paulo, mar. 2013. p. 333.
} 
Revista Eletrônica de Direito Processual - REDP.

Rio de Janeiro. Ano 11. Volume 18. Número 1. Janeiro a Abril de 2017

Periódico Quadrimestral da Pós-Graduação Stricto Sensu em Direito Processual da UERJ

Patrono: José Carlos Barbosa Moreira. ISSN 1982-7636. pp. 42-67

www.redp.uerj.br

Em termos mais pragmáticos, o Procurador da República responsável por diversos acordos de colaboração no âmbito da já mencionada operação Lava Jato, Deltan Dallagnol, em entrevista concedida à Folha de São Paulo, obtempera ${ }^{18}$ :

Nos acordos de colaboração, o princípio é que se troca um peixe por um cardume, ou um peixe pequeno por um peixe grande (...). As colaborações são feitas para alcançar provas em relação a diversas outras pessoas, incluindo criminosos com atuação mais relevante no crime, e para recuperar o dinheiro desviado. (..) O ideal, sem dúvidas, é que todos fossem punidos integralmente. Contudo, nesse caso, o ótimo é inimigo do bom.

Em linhas gerais, pode-se dizer que o fundamento dos benefícios está, justamente, numa proteção maior aos bens jurídicos que parecem desprotegidos com o afrouxamento das sanções criminais.

Não se tem, de um lado, a proteção desses bens jurídicos, e de outro, a busca irrefreável pela efetividade do processo penal, como querem fazer crer alguns. Neste caso, o fundamento e a crítica se confundem, e parecem objetar qualquer tentativa de se repelir a utilização da colaboração.

Afinal, em sua essência, o instituto da colaboração premiada visa sempre a ampliar o alcance do poder punitivo estatal, permitindo uma resposta mais abrangente e eficiente do Direito Penal frente a delitos que, sem esse mecanismo, restariam desconhecidos e impunes.

Sacrifica-se a medida exata da punição socialmente aguardada em face de um determinado agente para, a partir de suas declarações, alcançar diversos outros agentes e reparar, o quanto possível, os danos causados pela atividade criminosa. Ou seja, permite-se um enfraquecimento episódico da proteção conferida pelo Estado aos bens jurídicos fundamentais para, em outro momento, promover sua proteção de maneira muito mais eficiente e de forma muito mais expressiva em relação àquilo que se deixou de punir.

Além disso, é válido lembrar, o sistema penal brasileiro já reconhece, de certa forma, um abrandamento na culpabilidade daquele que abandona sua posição de resistência

18 Folha de São Paulo. Disponível em http://www1.folha.uol.com.br/poder/2016/01/1730595-gracas-aacordos-pena-de-delatores-da-lava-jato-cai-de-283-para-7-anos.shtml. Acesso em 22 out. 2016. 
Revista Eletrônica de Direito Processual - REDP.

Rio de Janeiro. Ano 11. Volume 18. Número 1. Janeiro a Abril de 2017

Periódico Quadrimestral da Pós-Graduação Stricto Sensu em Direito Processual da UERJ

Patrono: José Carlos Barbosa Moreira. ISSN 1982-7636. pp. 42-67

www.redp.uerj.br

e passa a colaborar com o deslinde do processo penal. É exatamente esse o caso do réu que, a partir de sua confissão, passa a fazer jus à atenuação de sua pena.

Ora, se a partir de sua confissão esse mesmo réu pode, além de colaborar com o deslinde de seu próprio caso, ainda incrementar a eficácia e a utilidade da persecução penal, certamente, a partir do mesmo fundamento que guia a lógica do Código Penal, poderá também fazer jus a uma punição mais branda.

Talvez, por isso, muito mais produtivo seja voltar as atenções não à crítica abstrata dos institutos, mas ao seu aperfeiçoamento, com vistas a garantir a integral aplicação das balizas legalmente estabelecidas para a concessão das benesses pretendidas pelo colaborador, como forma, justamente, de se garantir que o resultado social obtido compense qualquer abrandamento na resposta estatal, e que, consequentemente, seja válido o juízo prévio realizado pelo legislador ordinário.

\subsection{O DIREITO FUNDAMENTAL À NÃO AUTOINCRIMINAÇÃO}

Outra crítica que merece atenção reside na menção a uma suposta vulneração do direito fundamental à não autoincriminação do pretenso delator. A objeção tem como pressuposto a necessidade de que o delator confesse sua participação no esquema criminoso e renuncie expressamente ao direito de se manter silente sobre aquilo que lhe for perguntado.

Vale lembrar, aqui, que essa renúncia ao direito ao silêncio, como aliás ocorre em relação a todo o procedimento da colaboração, partirá sempre de uma manifestação de vontade livre e consciente do sujeito passivo da persecução penal.

Não parece ser muito diferente da situação observada em relação ao réu que decide, no momento de seu interrogatório, confessar a prática delitiva, renunciando de maneira clara ao seu direito à não autoincriminação. Ou mesmo daquele que decide ir além e, sem a celebração de qualquer acordo de delação, colaborar com o esclarecimento dos fatos e fornecer informações sobre a prática delitiva.

Certamente, nenhuma das duas situações sobre qualquer objeção por parte da doutrina. Não se questiona a vulneração ao direito à não autoincriminação gerado pelo benefício concedido pelo Código Penal àquele que confessa a prática delitiva. E, 
Revista Eletrônica de Direito Processual - REDP.

Rio de Janeiro. Ano 11. Volume 18. Número 1. Janeiro a Abril de 2017

Periódico Quadrimestral da Pós-Graduação Stricto Sensu em Direito Processual da UERJ

Patrono: José Carlos Barbosa Moreira. ISSN 1982-7636. pp. 42-67

www.redp.uerj.br

seguramente, não se questionará a validade das informações prestadas por aquele que colaborar de maneira informal.

Ora, o direito a se manter silente ou a não colaborar de qualquer forma com a persecução penal, embora possam ser sempre exercidos pelos acusados de maneira geral, não se cuidam, absolutamente, de direitos irrenunciáveis por manifestação livre e consciente de vontade de seus titulares.

Inexiste uma obrigação do réu em resistir à persecução. Seja por questões de estratégia ou mesmo de consciência, a confissão e a colaboração sempre serão opções disponíveis, independente da roupagem que venham a assumir no curso do processo.

\subsection{DIREITO PENAL DE EMERGÊNCIA}

Todas as objeções doutrinárias voltadas ao instituto da delação parecem possuir um ponto de contato, qual seja, o rompimento com a linha evolutiva da humanização do direito penal a partir da adoção de um modelo de emergência, ao arrepio dos Direitos e Garantias Fundamentais dos sujeitos passivos da persecução criminal.

A partir da doutrina de Luigi Ferrajoli, argumenta-se que a incorporação da colaboração premiada no direito pátrio rompe com a ideia do modelo garantista, anexando práticas policialescas, com vistas à eficiência a qualquer custo.

Diz-se que tal prática maximiza de forma indevida o campo de abrangência do Direito Penal, gerando mega investigações e megaprocessos, que, no cipoal de sua inerente complexidade, aniquilam de forma disfarçada o direito ao exercício da ampla defesa.

O próprio jurista italiano, em obra clássica ${ }^{19}$, desenha sua visão do instituto:

Evidentemente, estos sistemas han conseguido éxito, También porque los fracasos - es decir, el castigo de los inocentes o la sobredefinición de las culpas - no podían hacerse visibles. El mecanismo inquisitivo puesto en pie pela emergencia ha sido de hecho, en muchos de estos procesos, eminentemente autorreflexivo: una vez formulada la acusación, la prisión seguía automáticamente y funcionaba como prueba de fuerza sobre el imputado, que no tenía más vías de salida defensivas que las de acusar,

\footnotetext{
${ }^{19}$ FERRAJOLI, Luigi. Derecho y razón: Teoría del garantismo penal. 4 ed. Madrid: Trotta, 2000. P. 824-824.
} 
Revista Eletrônica de Direito Processual - REDP.

Rio de Janeiro. Ano 11. Volume 18. Número 1. Janeiro a Abril de 2017

Periódico Quadrimestral da Pós-Graduação Stricto Sensu em Direito Processual da UERJ

Patrono: José Carlos Barbosa Moreira. ISSN 1982-7636. pp. 42-67

www.redp.uerj.br

acusarse o invocar clemencia. (...) Pero los instrumentos ofrecidos a la

magistratura por la legislación de segunda fase de la emergencia han distorsionado profundamente el método procesal: ya no la carga de la prueba para la acusación y el juicio contradictorio con la defensa, sino los métodos expeditivos - presiones sobre los imputados e obtención de sus confesiones y sus denuncias a los coimputados - que siempre han caracterizado a las ineptitud y a los malos hábitos policiales. (...) las normas sobre los arrepentidos y el uso de la prisión preventiva como medio inquisitivo han rebajado frecuentemente nuestra justicia a práctica policial, incluso en los otros dos aspectos, al haber conferido al poder judicial poderes y funciones que son algo distinto de la función jurisdiccional. Nada, en efecto, es más discrecional que el poder inquisitivo que tiene como fin la confesión o colaboración del imputado por medio de ese tormentoso moderno que es la prisión preventiva y la incertidumbre de la pena comparadas con su contención procesal.

E ressalta, a partir dessas mesmas ponderações, e de modo especialmente enfático, a utilização constante de prisões preventivas como meio de coerção para obtenção de acordos de delação ${ }^{20}$ :

Por otra parte, el gigantismo procesal ha representado a su vez un terreno propicio para cualquier abuso posible. Es sobre todo gracias a ello como ha podido desarrollarse el perverso maridaje entre prisión preventiva y colaboración premiada con la acusación: la primera utilizada como medio de presión sobre los imputados para obtener a ellos la segunda, y esta, como instrumento de ratificación de la acusación, as veces más allá de toda verificación e incluso de los careos con los coimputados denunciados.

É válido lembrar que são comuns, inclusive na imprensa ${ }^{21}$, as críticas direcionadas à já referida Operação Lava Jato pela suposta utilização de prisões provisórias para forçar a

\footnotetext{
${ }^{20}$ FERRAJOLI, Luigi. Derecho y razón: Teoría del garantismo penal. 4 ed. Madrid: Trotta, 2000. p. 823.
} 
Revista Eletrônica de Direito Processual - REDP.

Rio de Janeiro. Ano 11. Volume 18. Número 1. Janeiro a Abril de 2017

Periódico Quadrimestral da Pós-Graduação Stricto Sensu em Direito Processual da UERJ

Patrono: José Carlos Barbosa Moreira. ISSN 1982-7636. pp. 42-67

www.redp.uerj.br

obtenção de acordos de delação. Evidente que análise concernente à veracidade dessas

afirmações demanda um exame caso a caso dos diversos processos que resultam da mencionada operação, o que foge completamente aos estreitos limites deste trabalho.

Embora respeitáveis, essas objeções, a par do que já se argumentou até aqui, não possuem o condão de demonstrar a incompatibilidade da delação premiada com o sistema de Direitos e Garantias fundamentais do acusado, ou mesmo inviabilizar sua utilização na prática forense.

A crítica ao instituto não pode partir de um ponto abstrato. Faz-se necessário, antes de tudo, que se observe a regulamentação que a colaboração recebeu no direito infraconstitucional para, somente então, questionar a respeito de sua harmonia com os princípios constitucionais.

Basta que se observe que muitos dos problemas apontados na doutrina de Luigi Ferrajoli - e de tantos autores nacionais que criticam a utilização da delação premiada são resolvidos, como já demonstrado alhures, pela disciplina instituída pela Lei 12.850/2013, ou mesmo pela legislação já vigente no país.

Por exemplo, a questão do papel do juiz perante os acordos de delação, com vistas a que o magistrado não se torne uma espécie de autoridade policial-jurisdicional. A norma é clara em retirar do juiz qualquer participação na formação dos acordos de colaboração, função que caberá à acusação ou à autoridade policial, ao lado da defesa técnica. Não fosse isso, a lei ainda é clara em determinar ao juiz que zele pela observância dos Direitos e Garantias fundamentais do colaborador, inclusive no tocante ao cumprimento, pela acusação, de seu ônus probatório.

Do mesmo modo, no tocante às prisões provisórias, em qualquer de suas modalidades, a lei processual é clara quanto às hipóteses de seu cabimento, havendo parâmetros relativamente claros, na jurisprudência, a respeito de seu prazo de duração - no caso das preventivas.

Aliadas essas previsões, à faculdade constitucional do habeas corpus, aos pedidos de liberdade provisória e/ou revogação de prisão, e aos recursos inerentes ao processo,

\footnotetext{
${ }^{21}$ Em entrevista ao Estadão, o ex-Ministro do Superior Tribunal de Justiça, atualmente advogado, Gilson Dipp, critica que "acabou por ser a única forma de obtenção de provas, a partir de prisões preventivas ou temporárias atemporais”. Portal Estadão. Disponível em http://politica.estadao.com.br/noticias/geral,delacaona-lava-jato-ja-reduz-penas-em-326-anos,10000063321. Acesso em 22 out. 2016.
} 
Revista Eletrônica de Direito Processual - REDP.

Rio de Janeiro. Ano 11. Volume 18. Número 1. Janeiro a Abril de 2017

Periódico Quadrimestral da Pós-Graduação Stricto Sensu em Direito Processual da UERJ

Patrono: José Carlos Barbosa Moreira. ISSN 1982-7636. pp. 42-67

www.redp.uerj.br

tem-se um conjunto de postulados bastante capazes de limitar e guiar o papel do juiz na condução do processo em que haja a figura do atual ou potencial colaborador.

Não se está, como já dito antes, a ignorar os riscos de que abusos venham a ser cometidos. Contudo, deve-se observar que a forma legislada entrega uma margem de segurança bastante razoável para que se exija e fiscalize o respeito, por parte de todas as autoridades, dos princípios constitucionais inerentes à persecução penal.

O que se quer dizer com isto, mais uma vez, é que as energias devem ser voltadas não às objeções, mas à fiscalização e ao desenvolvimento de meios para evitar que as tão temidas arbitrariedades venham a ocorrer na prática.

Até porque, como bem salienta Márcio Barra Lima ${ }^{22}$ :

Todavia, aludido dissenso doutrinário não tem o condão de afastar o reconhecimento de que o mecanismo da colaboração premiada é uma tendência mundial e objetiva suprir os anseios da sociedade relativamente ao aperfeiçoamento do Direito, no sentido de conferir melhores condições (técnicas e materiais) aos juízes, membros do Ministério Público e integrantes da polícia judiciária no exercício das respectivas atividades de persecução penal.

Aliás, não é à toa que a utilização da delação premiada é, inclusive, recomendada por organismos internacionais como a União Europeia e a Organização das Nações Unidas (ONU), justamente como forma eficaz no combate às organizações criminosas ${ }^{23}$.

$\mathrm{Na}$ mesma medida que a sociedade e as formas criminosas evoluem para incorporar mecanismos mais sofisticados e limitadores do alcance estatal, deve este mesmo Estado, como detentor único do jus puniendi e titular quase absoluto das ações penais, evoluir em igual medida na proteção dos direitos fundamentais de seus cidadãos (aqui, evidentemente, em sentido amplíssimo).

\footnotetext{
${ }^{22}$ LIMA, Márcio Barra, A colaboração premiada como instrumento constitucionalmente legítimo de auxílio à atividade estatal de persecução criminal. In: CALABRICH, Bruno. FISCHER, Douglas. PELELLA, Eduardo. Garantismo Penal Integral: questões penais e processuais, criminalidade moderna e a aplicação do modelo garantista no Brasil. 1. ed. Salvador: Juspodivm, 2010.

${ }^{23}$ No âmbito das Nações Unidas, a recomendação está formalizada na Resolução da Assembleia Geral $n^{\circ}$ 55/25, concebida na Convenção das Nações Unidas sobre o Crime Organizado, em 2000, e que prevê a redução de pena e a "imunidade judicial" aos colaboradores. No âmbito da União Europeia, destaca-se a Resolução CE de 20 de novembro de 1996.
} 
Revista Eletrônica de Direito Processual - REDP.

Rio de Janeiro. Ano 11. Volume 18. Número 1. Janeiro a Abril de 2017

Periódico Quadrimestral da Pós-Graduação Stricto Sensu em Direito Processual da UERJ

Patrono: José Carlos Barbosa Moreira. ISSN 1982-7636. pp. 42-67

www.redp.uerj.br

Do contrário, não faria sentido punir o exercício arbitrário das próprias razões e manter-se em postura de convalescência com a prática criminosa sob argumento de apego a velhos dogmas jurídicos e a temores meta-racionais.

Segurança pública, vida, propriedade, probidade administrativa, entre outros, são todos valores fundamentais protegidos constitucionalmente e que, ao que parece, devem prevalecer sobre supostos códigos de ética criminosos ou mesmo flexibilizações dos arcaicos procedimentos que inviabilizam o trâmite e a conclusão dos processos criminais.

Preservadas as garantias do contraditório, da ampla defesa (inclusive técnica), do direito à não autoincriminação, da imparcialidade do magistrado, da separação das funções de acusador e julgador, da publicidade, enfim, de todos os atributos inerentes à dignidade do acusado, parece a hora de se admitir uma nova roupagem do devido processo legal, capaz de alcançar processos nos quais se desenvolve a figura da colaboração.

\section{CONCLUSÃO}

Não se tem, a partir do presente trabalho, a ingenuidade de acreditar que a adoção ampla e irrestrita do instituto em nosso sistema não seja capaz de vulnerar as garantias fundamentais do acusado frente ao poder punitivo do Estado. Os riscos, de fato, existem.

Entretanto, os mesmos fatos que trouxeram a delação premiada de volta aos holofotes das discussões acadêmicas demonstram, sem dúvidas, a utilidade e a necessidade do instituto no combate à criminalidade organizada, sendo difícil - senão impossível imaginar resultados práticos semelhantes sem as figuras dos colaboradores.

Nesse passo, deve-se reconhecer a pertinência dos argumentos favoráveis ao instituto - muitas vezes tachados, preconceituosamente, de utilitaristas - mas sem perder de vista a necessidade de seu aprimoramento constante, afim, justamente, de garantir que sua utilização não sirva de pretexto ao cometimento de arbitrariedades.

Afinal, sua adoção em nosso sistema data de pelo menos 26 (vinte e seis) anos, sem qualquer rejeição por parte da jurisprudência. Além disso, cuida-se de tendência observada em muitos países com largo desenvolvimento em matéria de Direitos e Garantias Fundamentais $^{24}$, e mesmo em organismos internacionais, como já visto.

\footnotetext{
${ }^{24}$ A afirmação é feita com base em estudo de Jorge Figueiredo Dias, que aponta a expansão de modalidades de consenso em diversos países, como Portugal, Alemanha, Itália, Espanha e Brasil. DIAS, Jorge de
} 
Revista Eletrônica de Direito Processual - REDP.

Rio de Janeiro. Ano 11. Volume 18. Número 1. Janeiro a Abril de 2017

Periódico Quadrimestral da Pós-Graduação Stricto Sensu em Direito Processual da UERJ

Patrono: José Carlos Barbosa Moreira. ISSN 1982-7636. pp. 42-67

www.redp.uerj.br

Como se viu ao longo deste trabalho, as críticas dirigidas ao instituto são facilmente superáveis, sobretudo se respeitada a regulamentação ditada pela Lei 12.850/2013.

Assim, muito mais frutíferas são as tentativas de aprimorar o instituto e de balizar sua aplicação à luz dos direitos e garantias fundamentais dos acusados, ao invés da simples repetição de argumentos desfavoráveis, muitas vezes dotados de um exacerbado conteúdo retórico e calcado numa suposta castidade do direito penal, como se fosse algo sagrado, intocável e imutável.

Em outras palavras, deve-se abandonar o tom puramente crítico para se adotar um tom propositivo, visando, justamente, a evitar que as tão propaladas violações aos direitos e garantias individuais venham a ser concretizar no dia a dia forense.

Não há sentido em homenagear sempre a posição de resistência do réu como se fosse algo necessário à própria validade da punição. A amenização do antagonismo, desde que guiada pela observância do devido processo legal, do contraditório, da ampla defesa, da presunção de não culpabilidade, do direito à autoincriminação e de todas as demais garantias inerentes à dignidade da pessoa humana, deve ser bem recepcionada pelo processo moderno.

Nas palavras do autor português, Jorge Figueiredo Dias, o processo penal moderno “deve dar passos decisivos na incrementação, em toda a medida possível, de estruturas de consenso em detrimento de estruturas de conflito entre os sujeitos processuais". Esse influxo, prossegue o Autor, funciona "como forma de oferecer futuro a um processo penal dotado de eficiência funcionalmente orientada indispensável à ultrapassagem da atual sobrecarga da justiça penal, sem menoscabo dos princípios constitucionais adequados ao Estado de Direito."25

A delação premiada, como uma dessas manifestações de espaços de consenso respeitadas suas peculiaridades - , guarda todos os requisitos para figurar em nosso arcabouço legislativo, como ferramenta importante à disposição do Estado e da sociedade, não como maneira de instituir um Direito Penal máximo, mas como forma de garantir que o Direito Penal possa atingir trincheiras antes inalcançáveis, onde se escondem delitos da máxima nocividade social.

Figueiredo. Acordos sobre a sentença em processo penal: o fim do Estado de Direito ou um novo princípio? Porto. Conselho Distrital do Porto: 2011.

${ }^{25}$ DIAS, Jorge de Figueiredo. Acordos sobre a sentença em processo penal: o fim do Estado de Direito ou um novo princípio? Porto. Conselho Distrital do Porto: 2011. p. 


\section{REFERÊNCIAS BIBLIOGRÁFICAS}

BITTAR, Walter Barbosa. Delação Premiada: Direito Estrangeiro, Doutrina e Jurisprudência. 2 ed. Rio de Janeiro: Lumen Juris, 2011.

BRASIL. Constituição da República Federativa do Brasil, de 5 de outubro de 1988. Brasília, $\quad 1988 . \quad$ Disponível em: < http://www.planalto.gov.br/ccivil_03/constituicao/constituicaocompilado.htm>. Acesso em: 3 dez. 2016.

BRASIL. Decreto-Lei No 2.848, de 7 de dezembro de 1940. Código Penal. Disponível em: <http://www.planalto.gov.br/ccivil_03/decreto-lei/Del3689Compilado.htm>. Acesso em: 3 dez. 2016.

BRASIL. Lei 12.850/2013, de 2 de agosto de 2013. Define organização criminosa e dispõe sobre a investigação criminal, os meios de obtenção da prova, infrações

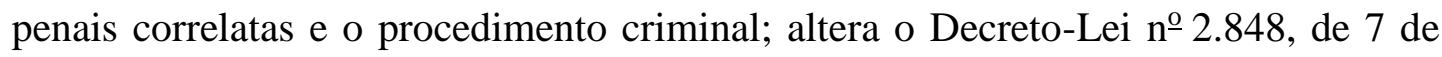
dezembro de 1940 (Código Penal); revoga a Lei no 9.034, de 3 de maio de 1995; e dá outras providências.

Disponível

em: <http://www.planalto.gov.br/ccivil_03/_ato2011-2014/2013/lei/112850.htm>. Acesso em: 3 dez. 2016.

DIAS, Jorge de Figueiredo. Acordos sobre a sentença em processo penal: o fim do Estado de Direito ou um novo princípio? Porto. Conselho Distrital do Porto: 2011. FERRAJOLI, Luigi. Derecho y razón: Teoría del garantismo penal. 4 ed. Madrid: Trotta, 2000.

Folha de São Paulo. Graças a acordos, penas de delatores da Lava-Jato caem de 283 para 7 anos. Disponível em http://www1.folha.uol.com.br/poder/2016/01/1730595gracas-a-acordos-pena-de-delatores-da-lava-jato-cai-de-283-para-7-anos.shtml. Acesso em 22 out. 2016.

LIMA, Márcio Barra, A colaboração premiada como instrumento constitucionalmente legítimo de auxílio à atividade estatal de persecução criminal. In: $\mathrm{CALABRICH}$, Bruno. FISCHER, Douglas. PELELLA, Eduardo. Garantismo Penal Integral: questões penais e processuais, criminalidade moderna e a aplicação do modelo garantista no Brasil. 1. ed. Salvador: Juspodivm, 2010. 
Revista Eletrônica de Direito Processual - REDP.

Rio de Janeiro. Ano 11. Volume 18. Número 1. Janeiro a Abril de 2017

Periódico Quadrimestral da Pós-Graduação Stricto Sensu em Direito Processual da UERJ Patrono: José Carlos Barbosa Moreira. ISSN 1982-7636. pp. 42-67 www.redp.uerj.br

NUCCI, Guilherme de Souza. Manual de Direito Penal: parte geral: parte especial. $3^{\text {a }}$ Ed. São Paulo: Editora Revista dos Tribunais, 2007.

PEREIRA, Frederico Valdez. Compatibilização Constitucional da Delação Premiada. Revista dos Tribunais, vol. 929, São Paulo, mar. 2013.

Portal Estadão. Delação na Lava-Jato reduz penas em 326 anos. Disponível em http://politica.estadao.com.br/noticias/geral,delacao-na-lava-jato-ja-reduz-penas-em326-anos,10000063321. Acesso em 22 out. 2016.

VASCONCELLOS, Vinicius Gomes de. Barganha e Justiça Criminal Negocial: análise das tendências de expansão dos espaços de consenso no processo penal democrático. São Paulo, IBCCrim: 2015. 